\title{
Effects of a New Anti-Inflammatory Imidazole Derivative, Fenflumizole, on Platelet Aggregation in the Rabbit
}

\author{
Junichiro AONO, Hiroyuki NABATA and Kazushige SAKAI* \\ Department of Pharmacology. Research Laboratories. Chugai Pharmaceutical Co., Ltd., \\ Takada, Toshima-ku. Tokyo 171. Japan \\ Accepted October 1.1986
}

\begin{abstract}
The antiplatelet effect of fenflumizole, compared with aspirin or ticlopidine, was examined in in vitro, ex vivo and in vivo situations of the rabbit. Unlike ticlopidine, fenflumizole and aspirin effectively inhibited in vitro the platelet aggregation elicited by arachidonate and collagen. The activity of fenflumizole was 350 times more potent than that of aspirin. Fenflumizole $(0.3-3 \mathrm{mg} / \mathrm{kg})$ given p.o. was 4.2 and 8.1 times more potent than aspirin in inhibiting arachidonate- and collagen-induced platelet aggregations, respectively. Ticlopidine $(300 \mathrm{mg} / \mathrm{kg}$, p.o.) resulted in only weak effects on the aggregations. Fenflumizole $(3 \mathrm{mg} / \mathrm{kg})$ as well as aspirin $(10 \mathrm{mg} / \mathrm{kg})$ given p.o., unlike ticlopidine $(300 \mathrm{mg} / \mathrm{kg})$. effectively prevented the arachidonate-induced sudden death.
\end{abstract}

Fenflumizole is a non-steroidal imidazole derivative, possessing anti-inflammatory, analgesic and anti-pyretic activities similar to those of indomethacin (1). Recently, it has been revealed experimentally (2) and clinically $(3,4)$ that the drug exerts a potent inhibitory activity against platelet aggregation. The present study in the rabbit was carried out to evaluate further the antiaggregatory activity of fenflumizole. compared with that of aspirin or ticlopidine.

Male Japanese white rabbits, weighing about $3 \mathrm{~kg}$. were anesthetized lightly with sodium thiopental, $30 \mathrm{mg} / \mathrm{kg}$. i.v., and placed supinely on the operating table. The animals used for ex vivo and in vivo experiments were starved overnight before the experiment, but water was allowed ad libitum. and they were subjected to investigations in the conscious and restrained state in a quiet room.

In vitro studies: The blood was withdrawn from the cannulated left carotid artery into glass syringes containing $3.8 \%$ sodium citrate solution (citrate: blood=1:9). The blood was centrifuged for $10 \mathrm{~min}$ at $1300 \mathrm{rpm}(230 \times \mathrm{g})$. After platelet-rich plasma (PRP) was

\footnotetext{
* To whom correspondence should be addressed.
}

separated, the remaining aliquot was centrifuged for $10 \mathrm{~min}$ at $3000 \mathrm{rpm}(1300 \times \mathrm{g})$ and platelet-poor plasma (PPP) was obtained. A platelet counter (model ZBI, Coulter Electronics, U.S.A.) was used to adjust the number of platelets in PRP to a constant value $\left(5 \times 10^{5}\right.$ platelets $\left./ \mu l\right)$ in each experiment with homologous PPP. Each sample $(200 \mu l)$ was prewarmed for $5 \mathrm{~min}$ at $37^{\circ} \mathrm{C}$ and stirred at $1000 \mathrm{rpm}$ before addition of drugs. Then, $20 \mu l$ of drug solution or vehicle was added to each sample: and 2 min later, $20 \mu l$ of aggregating agents also were added. The final concentrations of aggregating agents were $200 \mu \mathrm{g} / \mathrm{ml}$ arachidonate, $20 \mu \mathrm{g} / \mathrm{ml}$ collagen and $10 \mu \mathrm{M}$ ADP, inducing about $80 \%$ of maximal aggregation. The aggregation curve was monitored by means of a blood platelet aggregometer (NKK platelet aggregation tracer, model PAT-4M, SSR Engineering Co., Japan). Inhibition of platelet aggregation was assessed by comparing maximal optical transmission changes of the drug-treated PRP sample with the vehicletreated PRP sample, and this was expressed as percentage changes.

Ex vivo studies: Under light anesthesia, the animals were tracheotomized, and the left carotid artery was exposed. The surgery 
incisions were covered with $2 \%$ lidocainesoaked cotton. After recovery from anesthesia, a $9 \mathrm{~cm}$ long polyethylene tubing (PE 90. Clay Adams, U.S.A.) with a three-way stop-cock, filled up with $3.8 \%$ citrate solution, was inserted from the carotid artery into the ascending aorta for collection of a blood sample. This procedure was repeated each time a blood sample was taken. Before and 1. 3.5 and $24 \mathrm{hr}$ after intragastric (p.o.) drug administration, $5 \mathrm{ml}$ of the blood samples were withdrawn to obtain PRP.

In vivo studies: The procedure was performed as described in the ex vivo studies. Just after recovery from anesthesia, the catheters were inserted into the left jugular vein and carotid artery for arachidonate application and blood samplings, respectively. The drug effects on platelet count changes and thromboembolic death induced by arachidonate $(2 \mathrm{mg} / \mathrm{kg}$ ) were determined $1 \mathrm{hr}$ after intragastric administration of drugs. The arachidonate solution was given i.v. for $10 \mathrm{sec}$. Ten, 20 and $60 \mathrm{sec}$ just after the finish of the dosing, $2 \mathrm{ml}$ of blood was withdrawn from the carotid artery to obtain PRP at each time point. The platelet count was measured with a Coulter Counter.

The drugs used were: 2-(2,4-difluorophenyl) -4,5-bis (4-methoxyphenyl) imidazole, fenflumizole (M.W. 392.40, Dumex, Denmark), ticlopidine hydrochloride (Daiichi Seiyaku, Japan) (extracted from commercially available tablets), collagen (Hormonchemie, Germany), aspirin, arachidonate sodium salt (from porcine liver approx. 90\%) and ADP (adenosine 5'-diphosphate from equine muscle) (Sigma, U.S.A.). In ex vivo and in vivo studies, fenflumizole, aspirin and ticlopidine were suspended in $2 \%$ gum arabic solution and given p.o. in a volume of $1 \mathrm{ml} / \mathrm{kg}$. In the in vitro study, the three drugs were dissolved in $2 \%$ dimethyl sulfoxide and diluted with $0.9 \%$ saline solution. The other drugs were dissolved in $0.9 \%$ saline solution.

Results were expressed as means \pm S.E. Statistical evaluation was performed by Dunnett's test (5). Differences with $P$ values less than 0.05 were considered to be statistically significant.

In the in vitro studies, fenflumizole concentration-dependently inhibited arachido- nate- and collagen-induced platelet aggregations in the range of $3 \times 10^{-8} \mathrm{M}$ to $10^{-6}$ $M$. The $50 \%$ effective concentrations (EC50) of fenflumizole in inhibiting arachidonateand collagen-induced aggregations were $4.0 \times$ $10^{-7} \mathrm{M}$ and $1.7 \times 10^{-7} \mathrm{M}$. respectively. On the other hand, the EC50 values of aspirin in inhibiting arachidonate- and collageninduced aggregations were $1.4 \times 10^{-4} \mathrm{M}$ and $5.3 \times 10^{-5} \mathrm{M}$. respectively. The potency of fenflumizole in inhibiting the aggregations was approximately 350 times higher than that of aspirin. Even in the highest doses used, these drugs had little or only slight inhibitory effects on ADP-induced platelet aggregation $\left(10^{-6} \mathrm{M}\right.$ fenflumizole, $6.3 \pm 2.3 \% ; 10^{-3} \mathrm{M}$ aspirin, $17.3 \pm 1.1 \%$, each $n=5)$. Ticlopidine $\left(10^{-3} \mathrm{M}\right)$ only exerted a slight inhibitory activity on the arachidonate-, collagen- and ADP-induced aggregations $\quad(12.9 \pm 3.1 \%$. $26.6 \pm 2.6 \%$ and $23.8 \pm 1.6 \%$, respectively, each $n=5)$.

In ex vivo studies, fenflumizole given p.o. at doses of 0.3 to $3 \mathrm{mg} / \mathrm{kg}$ significantly inhibited both arachidonate- and collageninduced platelet aggregations in a dosedependent fashion (Fig. 1). The inhibitory effect against the aggregations reached its peak $1 \mathrm{hr}$ after the drug application, and it lasted over $5 \mathrm{hr}$. Aspirin given p.o. at 3 and $10 \mathrm{mg} / \mathrm{kg}$ effectively prevented arachidonateand collagen-induced platelet aggregations. However, compared with those of fenflumizole using the ED50 value estimated in the aggregations, its activities were 4.2 and 8.1 times, respectively, less than those of fenflumizole. Ticlopidine exerted only a weak effect on the aggregations, even in a high dose $(300 \mathrm{mg} / \mathrm{kg}$ ) (Fig. 1).

In in vivo studies, the i.v. injection of 2 $\mathrm{mg} / \mathrm{kg}$ arachidonate produced reversible falls in platelet counts, and all of the animals died within $5 \mathrm{~min}$. Figure 2 shows the effect of drugs on the thrombocytopenia induced by the arachidonate injection. Intragastric administration of $3 \mathrm{mg} / \mathrm{kg}$ fenflumizole and $10 \mathrm{mg} / \mathrm{kg}$ aspirin tended to inhibit the falls in platelet counts, although no significant differences were observed between the corresponding values obtained from the control and drug-treated groups. Four of the 5 rabbits treated with $3 \mathrm{mg} / \mathrm{kg}$ fenflumizole 

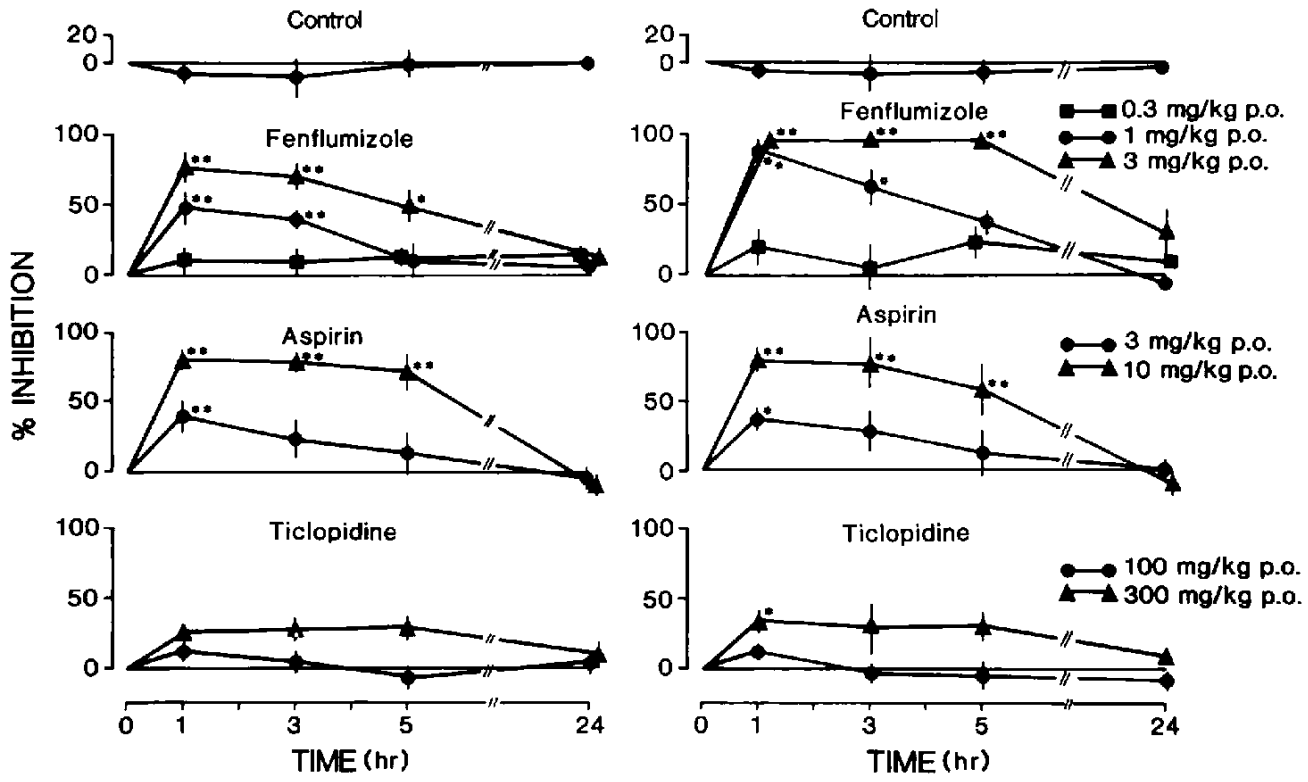

Fig. 1. Time course of the effects of fenflumizole, aspirin and ticlopidine administered p.o. on arachidonate- and collagen-induced platelet aggregations in rabbits. Each point represents the mean of 5 experiments, estimated by duplicate assay. Vertical bars show the S.E. of the mean. ${ }^{*} P<0.05$. ${ }^{* *} P<0.01$. compared to the corresponding values obtained from the control group. The control group was given orally $1 \mathrm{ml} / \mathrm{kg}$ of $2 \%$ gum arabic solution.

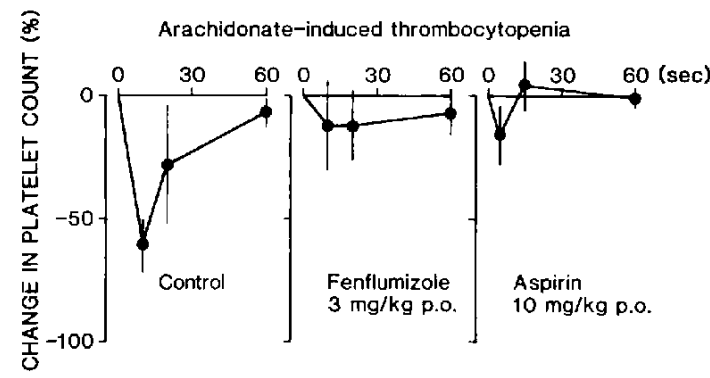

Fig. 2. Effects of fenflumizole and aspirin on thrombocytopenia induced by i.v. injection of $2 \mathrm{mg} /$ $\mathrm{kg}$ arachidonate in rabbits. Each point represents the mean of 5 experiments. Vertical bars show S.E. of the mean. The effects of i.v. application of $2 \mathrm{mg} / \mathrm{kg}$ arachidonate on platelet counts were determined $1 \mathrm{hr}$ after oral administration of drugs. Ten, 20 and $60 \mathrm{sec}$ just after stopping the injection of arachidonate solution, blood samples were collected. The control group was given orally $1 \mathrm{ml} / \mathrm{kg}$ of $2 \%$ gum arabic solution. and all of the 5 animals treated with $10 \mathrm{mg} / \mathrm{kg}$ aspirin were protected from arachidonateinduced death. On the other hand. $300 \mathrm{mg} / \mathrm{kg}$ ticlopidine failed to prevent both arachidonateinduced thrombocytopenia and sudden death (data not shown).

According to the report of Corell et al. (2), fenflumizole is a cyclooxygenase inhibitor. even though it was 18 times less active in inhibiting prostaglandin (PG) $E_{2}$ synthesis in vitro and 170 times weaker as an inhibitor of $\mathrm{PGI}_{2}$ generation in the rat stomach mucosa ex vivo than indomethacin. In the present experiment, fenflumizole as well as aspirin effectively prevented the arachidonate- and collagen-induced platelet aggregations, but did not significantly affect the ADP-induced aggregation. The aggregation elicited by arachidonate $(6,7)$. and collagen (8) depends greatly on the arachidonate pathway. Therefore, it is not surprising that fenflumizole, like aspirin, effectively inhibited the arachidonateand collagen-induced platelet aggregations. 
Thus it seems that fenflumizole induces antiplatelet effects through a mechanism similar to aspirin, but different from ticlopidine (9).

\section{References}

1 Corell, T. and Hasselmann, G.: Pharmacodynamics and toxicology of fenflumizole, a new non-steroidal anti-inflammatory imidazole derivative. Acta Pharmacol. Toxicol. 53, 288-296 (1983)

2 Corell, T., Hasselmann, G., Splawinski, J. and Wojtaszek, B.: Fenflumizole: interactions with the arachidonic acid cascade. Acta Pharmacol. Toxicol. 53, 297-303 (1983)

3 Vinge, E., Corell, T. and Andersson, K.E.: Effects of fenflumizole on aggregation ex vivo of human platelets and formation of thromboxane $\mathrm{B}_{2}$ and 6-keto-prostaglandin- $F_{1 \alpha}$. Eur. J. Clin. Pharmacol. 26, 711-717 (1984)

4 Grande, P., Wadt, J. and Corell, T.: Influence of fenflumizole on platelet aggregation in man.
Eur. J. Clin. Pharmacol. 27, 169-172 (1984)

5 Dunnett, C.W.: New tables for multiple comparisons with a control. Biometrics 20,482-491 (1964)

6 Hamberg, M., Svensson, J. and Samuelsson, B.: Thromboxanes: A new group of biologically active compounds derived from prostaglandin endoperoxides. Proc. Natl. Acad. Sci. U.S.A.72, 2994-2998 (1975)

7 Hamberg, M., Svensson, J., Wakabayashi, T. and Samuelsson, B.: Isolation and structure of two prostaglandin exdoperoxides that cause platelet aggregation. Proc. Natl. Acad. Sci. U.S.A. 71, 345-349 (1974)

8 Vargaftig, B.B., Chignard, $M$. and Benveniste, J.: Present concepts on the mechanisms of platelet aggregation. Biochem. Pharmacol. 30, 263-271 (1981)

9 Ashida, S. and Abiko, Y.: Mode of action of ticlopidine in inhibition of platelet aggregation in the rat. Thromb. Haemost. 41, 436-449 (1979) 